\title{
INFLUENCE OF VENEER QUALITY ON BEECH LVL MECHANICAL PROPERTIES
}

\author{
Abdelhakim Daoui ${ }^{1}$, Clément Descamps ${ }^{2}$, Rémy Marchal', Abdellatif Zerizer ${ }^{1}$
}

\begin{abstract}
The quality of peeled veneers is generally quoted considering 3 main criteria: surface roughness, thickness variations and lathe checking. This last criterion impacts on mechanical properties of byproducts. It is well known that lathe checking occurrence can be reduced applying a good hygrothermal treatment of the round-wood before peeling coupled with optimised setting of pressure bar on the peeling lathe. It is also well known that thicker the veneer is and more difficult it is to reduce lathe checking and the other veneer defects.

The tendency being to manufacture more eco-friendly engineering wood products using less glue, it is of interest to design such products with thicker layers and so less glue lines. But using ticker veneers should lead to a deterioration of final products mechanical properties.

To quantify this effect, we have made 20-21 mm thick LVL (Laminated Veneer Lumber) boards of beech (Fagus sylvatica) with various compositions (veneers 1, 3 or $5 \mathrm{~mm}$ thick). In order to obtained veneers enclosing different grades, several bolts of a same tree have been peeled following 4 different modalities changing wood conditioning temperature $\left(20 / 70^{\circ} \mathrm{C}\right)$ and pressure bar settings (bar acting or not).
\end{abstract}

The quality of all the veneers has been quantified before gluing. In total, 12 sets of boards have been produced for non destructive and destructive mechanical tests.

The main results of these exploratory experiments are:

- a quite low weakening of LVL mechanical properties when increasing veneer thickness.

- the non destructive prediction of MOE by vibration seems not so good on LVL with thick veneers, especially in the case of edgewise loading, probably because of the presence of important lathe checks.

- in some configuration, and especially when using thick veneers, it could be benefit to load LVL flatwise rather than edgewise.

- for the measurement of shear strength on LVL, the 5-point bending test increases its efficiency when increasing veneer thickness.

To properly order in a hierarchy the different veneer criteria impacting on LVL mechanical properties, new tests should be repeated on different LVL boards homogeneous for given criteria of veneer quality.

Keywords: LVL, lathe checks, veneer quality, mechanical properties, beech

\footnotetext{
\$This paper was originally presented at the 2010 IAWS/ESTB7 meeting, Rabat-Morocco, March 2010, and has been updated

${ }^{1}$ Universite M'hamed Bougara de Boumerdès, LMMC, avenue de l'Indépendance 35000 Boumerdès, Algeria

${ }^{2}$ Arts et Metiers ParisTech, LABOMAP, rue Porte de Paris 71250 Cluny, France, remy.marchal@ensam.eur

Corresponding author : daouiabdelhakim@yahoo.fr

Received : 07.06. 2010 Accepted : 17.12.2010.
} 


\section{INTRODUCTION}

LVL (Laminated Veneer Lumber) is now well-known to be a high-performance Engineering Wood Product (EWP) for construction. The drawback of such material is that the part of the glue inside can reach important ratio until $20 \%$, LVL ecobalance is then debased compared to solid wood one. Increasing veneer thickness would help to decrease glue consumption.

During the seventies and eighties, many researches, especially in North America, have studied the influence of veneer thickness on LVL mechanical properties. It was a period devoted to the adjustment of LVL process, just before the real first LVL industrial business. The purpose was already to reduce the consumption of glue and to find a compromise between this concern and the mechanical performance.

Thus, Schaffer et al. 1972 have studied the influence of layers number (3, 4 or 6 veneers) on bending strength mean values and dispersion of LVL with the same section and loaded edgewise. It appears that (i) mechanical values increased with the number of veneers (6-ply LVL showed the best mechanical properties) (ii) results obtained on 4-ply LVL are close to those of solid wood in the medium class, however showing less dispersion. (iii) results on 6-ply LVL show the lower variability and a bending strength two times higher than the one of medium solid wood.

Leicester and Bunker 1969 in Moody 1972 demonstrated on 3-ply LVL that tension strength is a linear function of the inverse of veneer thickness. Youngquist and Bryant 1979, Preston 1950 in Kunesh 1978, Ebihara 1982, Youngquist et al. 1984 all confirmed this type of results.

Making analysis of variance, Hoover et al. 1987 found, a significant effect of the " number of layers» on bending strength both edgewise or flatwise (at 97\% confidence) of three hardwood species: the strength increased with number of layers. On the other hand, the authors did not find any significant effect on MOE (Modulus of Elasticity) or on shearing strength.

For Lei and Wilson 1979, orientation effects into wood become less marked under $0.8 \mathrm{~mm}$ in the case of Douglas-fir. This near disappearance of wood specific plans would make LVL constituted with thin veneers stronger than solid wood face to fracture propagation.

Ebihara 1982 observed that shear modulus G decreased when veneer thickness increase.

Kilic et al. 2006 shown on LVL made of black alder that the specific gravity and mechanical properties of the LVL produced from 2-mm veneers were higher compared to those from 4-mm veneers.

To sum up, veneer thickness decreasing generally goes with an improvement of mechanical properties. The authors attribute this relation to the higher impregnation rate of veneers and lathe checks with glue, to the random dispersion of defects into the board, but mainly to lathe checking that increases with veneer thickness. Watanuki et al. 1983, Moriizumi et al. 1984 explicitly confirmed the influence of lathe checks on the reduction of LVL MOE and MOR (Modulus of Ruptured) in bending.

But there are some times exceptions, e.g. Echols and Currier 1973 finding better results on solid wood than on 5-ply, and better on 5-ply than on 7-ply Douglas-fir LVL.

Most of these authors have worked on LVL composed with veneers in a range of thickness between $2.5 \mathrm{~mm}(1 / 10 \mathrm{inch})$ and $13 \mathrm{~mm}(1 / 2 \mathrm{inch})$, mainly from softwoods (southern pines, Douglas-fir) i.e. heterogeneous wood where the lathe checking patterns are not easy to characterize.

Even if all the results appear to go in the same direction, we did not find any sharp model of the lathe checks influence (pattern, depth, frequency) on the major mechanical characteristics. Such a model would 
be very useful in order to find the compromise between veneer thickness and mechanical properties for given wood species. Another advantage of peeling thick veneer would be to reduce production times on the peeling lathe, clippers, glue spreaders, assembling before pressing. On the other hand, thick veneer drying time would be longer.

We have conducted a pre-research program to approach such model of lathe checks influence on LVL mechanical performances, starting with beech wood because of its homogeneity and because this species is quite often peeled in France to make boards for furniture, chairs, interior of cars, skis. We have taken the opportunity of this research to measure some other veneer quality parameters like surface roughness and thickness variations for a first assessment of their real impact on LVL mechanical properties.

\section{MATERIALS AND METHODS}

\section{Sampling}

One beech tree (Fagus sylvatica) has been harvested in the State Forest "des Etangs" in Saône valley, Burgundy, France. The $\log (13 \mathrm{~m}$ long / mean diameter: $0.45 \mathrm{~m})$ has been crosscut into 20 bolts $0.6 \mathrm{~m}$ long each, numbered from 1 to 20 , the top of the log.

\section{Peeling}

Each bolt has been peeled following one of 12 conditions (Table 1) i.e 3 veneer thickness $(1,3,5 \mathrm{~mm}$ ) x 2 boiling temperatures $\left(20,70^{\circ} \mathrm{C}\right) \times 2$ pressure bar settings (no pressure bar / pressure bar acting).

Table 1. Peeling modalities (Bolts 4 and 14 have been each used for two modalities)

\begin{tabular}{|c|c|c|c|c|c|c|c|c|c|c|c|c|}
\hline Bolt number & 14 & 4 & 15 & 13 & 4 & 14 & 19 & 17 & 3 & 18 & 16 & 11 \\
\hline Veneer thickness [mm] & 1 & 3 & 5 & 1 & 3 & 5 & 1 & 3 & 5 & 1 & 3 & 5 \\
\hline Boiling temperature & \multicolumn{6}{|c|}{$20^{\circ} \mathrm{C}$} & \multicolumn{6}{|c|}{$70^{\circ} \mathrm{C}$} \\
\hline Pressure bar (PB) & \multicolumn{3}{|c|}{ Without BP } & \multicolumn{3}{|c|}{ With PB } & \multicolumn{3}{|c|}{ Without BP } & \multicolumn{3}{|c|}{ With PB } \\
\hline
\end{tabular}

The duration of the boiling treatment into water was $24 \mathrm{~h} \pm 1 \mathrm{~h}$ before peeling on A\&M ParisTech instrumented industrial peeling lathe (SEM Automation). The cutting speed was $1.5 \mathrm{~m} / \mathrm{s}$ until to reach a residual core with a diameter of $7 \mathrm{~cm}$. The clearance angle was maintained constant at $1^{\circ}$ and when the pressure bar was acting, the horizontal and vertical gaps values were respectively $90 \%$ and $30 \%$ of the veneer thickness.

\section{Veneer characterization}

After peeling, veneers have been clipped in $0.5 \mathrm{~m} \mathrm{x} 0.5 \mathrm{~m}$ sheets. The quality assessment of veneers has been made on green veneer, immediately after peeling, measuring roughness, thickness variations, lathe checks amplitude and frequency.

Roughness has been measured using an analog leakage meter (Figure 1), a pneumatic device based on the measurement of the air leakage between two metallic rings and the wood surface to characterize. The flow increasing with the surface roughness, the value of the residual pressure, read on a column of water, decreases. This value moves into a range of $120 \mathrm{~mm}$ (the worth surface) to $390 \mathrm{~mm}$ of water (the smoother surface). For each face of each squared veneer, the measurements have been repeated 5 times ( 4 measurements near the corners and 1 measurement in the middle of the veneer). We have computed the mean value and the differences between the values obtained on the loose-side and on the tight-side of the veneer, this difference being supposed to be correlated to the lathe checking occurrence. 


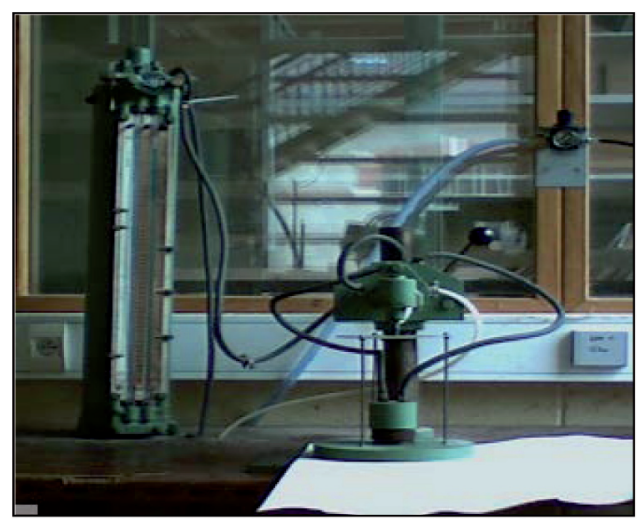

Figure 1. The leakage meter

To estimate thickness variations, we have measured the thickness of each veneer in 8 different points using a digital micrometer (Figure 2) weighed down with a mass in order to flatten veneers.

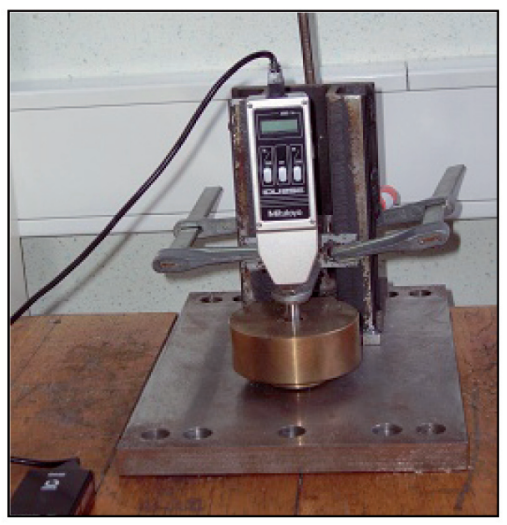

Figure 2. The digital micrometer

Lathe checks have been characterized using the SMOF device (Système de Mesure Optique des Fissurations - Pałubicki et al. 2009), which detect checks with a high speed line scan camera and a LDS (Laser Displacement Sensor) (Figure 3). We can automatically measured on the image obtained, the depth of the checks and the distance between two successive checks. (Figure 4).

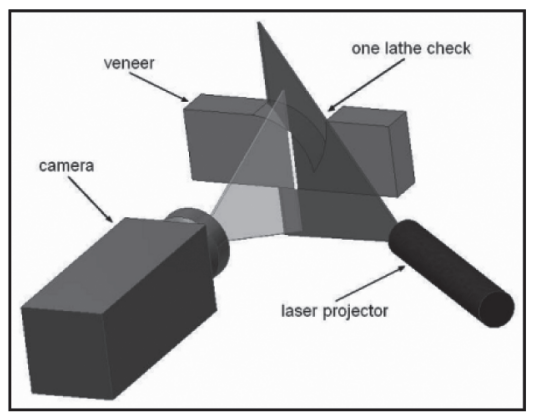

Figure 3.Principle of "SMOF" (Palubicki et al. 2009) 


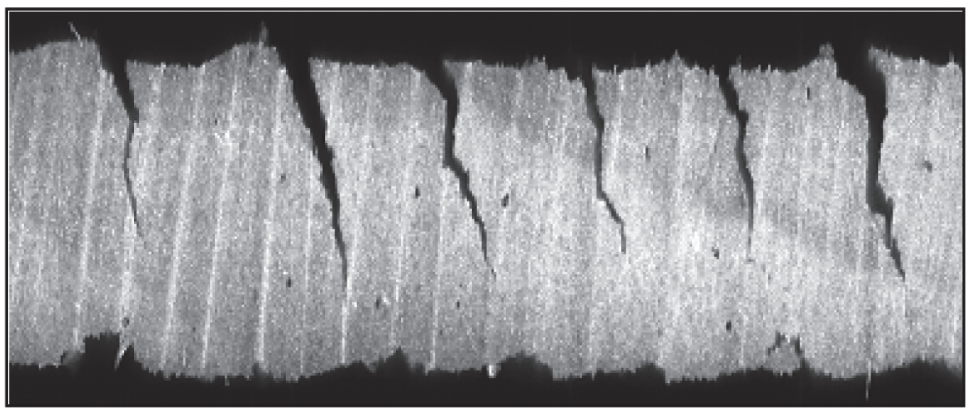

Figure 4. Resulting image on beech (loose face on the top)

\section{LVL boards manufacturing}

For each of the 12 peeling modalities, we have made 2 LVL boards $20 \mathrm{~mm}$ thick $(21 \mathrm{~mm}$ thick in the case of LVL with $3 \mathrm{~mm}$ thick veneers), $0.5 \mathrm{~m}$ wide and $0.5 \mathrm{~m}$ long (Figure 5). We have glued the veneers at 10\% MC (Moisture Content) with the MUF (melamine-urea-formaldehyde) resin "Prefere 4535 " of Icabois applying a spread rate of $300 \mathrm{~g} / \mathrm{m}^{2}$, a pressing temperature of $80^{\circ} \mathrm{C}$, a pressing time of 8 minutes under a pressure of $0.8 \mathrm{MPa}$.

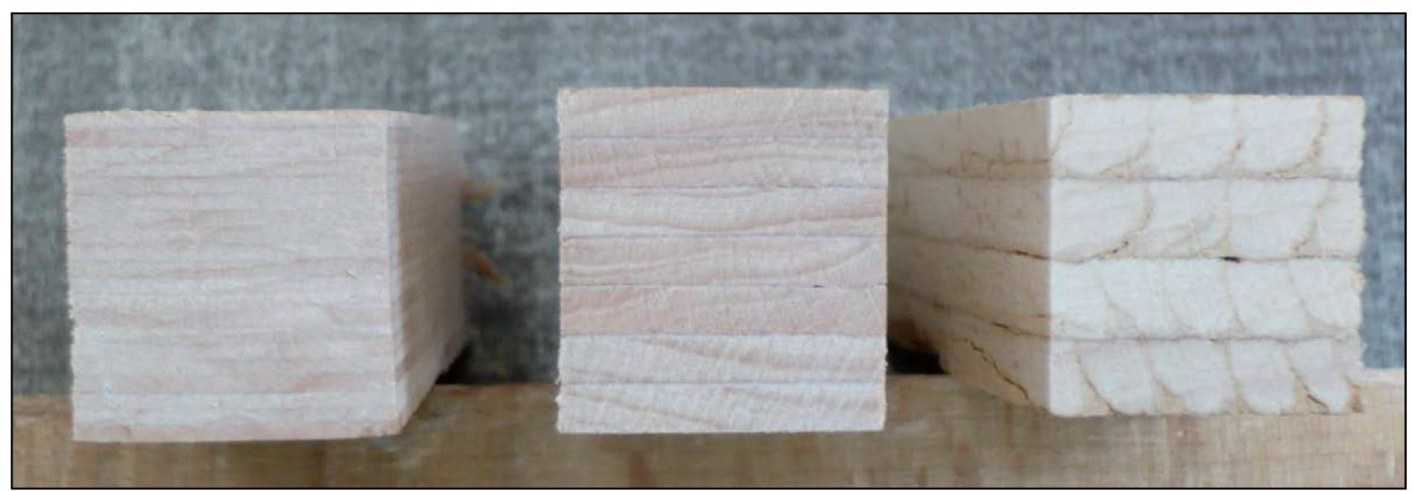

Figure 5. Cross section of the 3 kinds of sample (from the left to the right, LVL composed with $1 \mathrm{~mm}, 3 \mathrm{~mm}$ and $5 \mathrm{~mm}$ thick veneers)

\section{Mechanical tests}

In most cases, each board has been cut into 18 testing samples $20 \mathrm{~mm}$ thick, $20 \mathrm{~mm}$ wide, $0.5 \mathrm{~m}$ long in the longitudinal direction, i.e. 36 pieces per peeling modality. All these samples have been first characterized using a non-destructive vibration method (Bing 2007), each sample having been impacted flatwise then edgewise. We have computed the MOE following Bernoulli and Timoshenko models. Afterwards, the sampling has been divided in two: one half for 4-point bending tests performed edgewise and according to NF B51-008 and B51-016 standards to measure the static MOE and strength of rupture (Figure 6a) ; the other half for 5-point bending tests to obtain shearing strength values (ASTM D2718, Figure 6b). For this last test, the sampling has been divided again in two: one half has been tested flatwise and the other half edgewise in order to appreciate the possible influence of lathe checking respectively on the glue bonds strength and on the plies strength. 
(a)

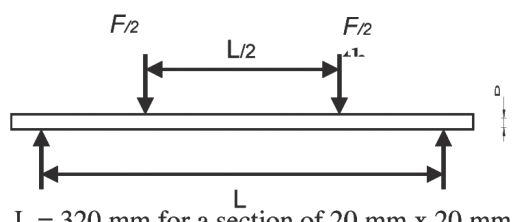

$\mathrm{L}=320 \mathrm{~mm}$ for a section of $20 \mathrm{~mm} \times 20 \mathrm{~mm}$ (b)

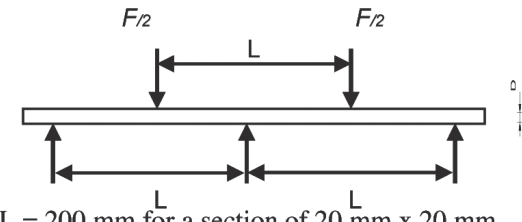

$\mathrm{L}=200 \mathrm{~mm}$ for a section of $20 \mathrm{~mm} \times 20 \mathrm{~mm}$

Figure 6. Geometry of the destructive tests (a) 4-point bending test (b) 5-point bending test

To sum up, for each peeling modality the tests have been repeated 18 times for the non destructive and the 4-point bending experiments but only 9 times (in most cases) for the 5-point ones.

\section{RESULTS AND DISCUSSION}

\section{Veneer quality}

Roughness increases, i.e. the residual air pressure into the leakage meter decreases (Table 2 and Figure 7)

- when veneer thickness increases

- using a pressure bar

- without hygrothermal preparation

- $\quad$ going from the loose-side to the tight-side of veneers.

Table 2. Roughness of green veneers

\begin{tabular}{|c|c|c|c|c|c|c|c|c|c|c|c|c|}
\hline Temperature & \multicolumn{9}{|c|}{$20^{\circ} \mathrm{C}$} & \multicolumn{7}{c|}{$70^{\circ} \mathrm{C}$} \\
\hline Veneer thickness (mm) & 1 & 3 & 5 & 1 & 3 & 5 & 1 & 3 & 5 & 1 & 3 & 5 \\
\hline Pressure bar & \multicolumn{3}{|c|}{ No PB } & \multicolumn{3}{c|}{ PB } & \multicolumn{3}{c|}{ No PB } & \multicolumn{3}{c|}{ PB } \\
\hline $\begin{array}{c}\text { Number of } \\
\text { measurements }\end{array}$ & 230 & 80 & 124 & 220 & 70 & 70 & 267 & 110 & 60 & 215 & 100 & 31 \\
\hline $\begin{array}{c}\text { (1) Loose-side } \\
\begin{array}{c}\text { Mean value } \\
\text { (mm of water) }\end{array}\end{array}$ & 209 & 139 & 124 & 257 & 153 & 126 & 250 & 141 & 134 & 327 & 156 & 164 \\
Coef. of variation (\%) & 19.7 & 10.7 & 9.0 & 13.3 & 15.6 & 9.5 & 14.8 & 16.4 & 18.2 & 5.4 & 18.7 & 15.4 \\
\hline $\begin{array}{c}\text { (2) Tight-side } \\
\text { Mean value } \\
\text { (mm of water) }\end{array}$ & 306 & 190 & 147 & 332 & 200 & 158 & 314 & 211 & 176 & 345 & 189 & 219 \\
Coef. of variation (\%) & 12.2 & 20.8 & 18.6 & 7.5 & 20.3 & 25.6 & 7.5 & 17.1 & 20.3 & 4.3 & 22.3 & 15.8 \\
\hline $\begin{array}{c}\text { (2)-(1) } \\
\text { (mm of water) }\end{array}$ & 97 & 51 & 23 & 75 & 47 & 32 & 64 & 70 & 42 & 18 & 33 & 55 \\
\hline
\end{tabular}




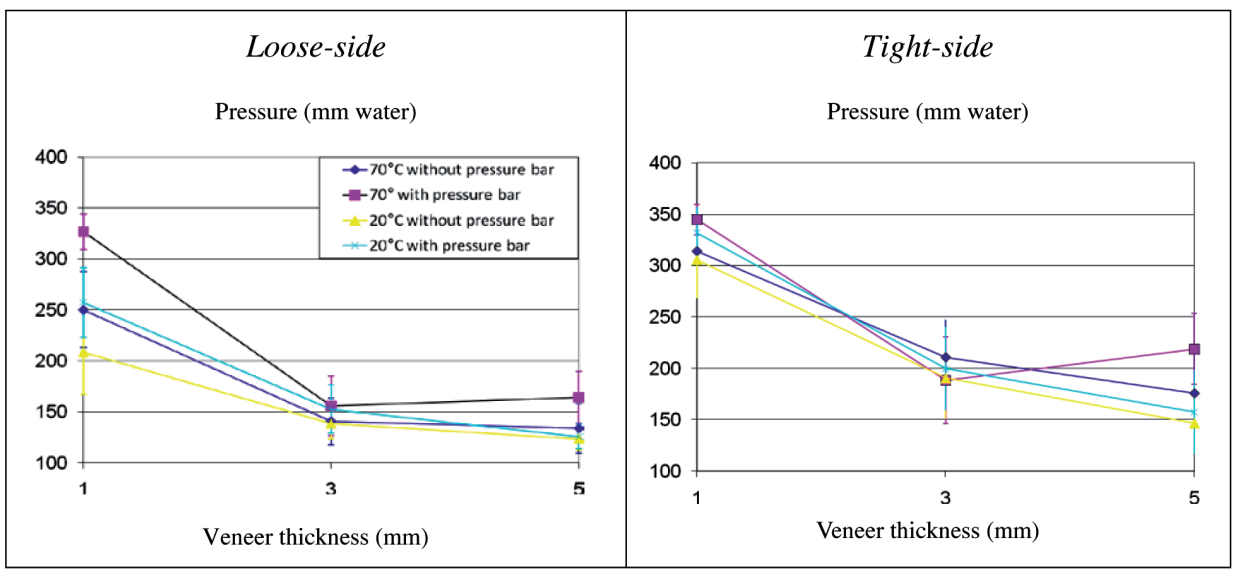

Figure 7. Variation of roughness for the different beech veneers (mean values $\pm \mathrm{sd}$ )

Obviously, the pneumatic method used does not measure only roughness but also a part of lathe checking. However it clearly appears that higher the thickness is and lower is the difference of "roughness" between the two faces: lathe checks getting worse, their influences on the surface quality of the veneer loose-side produced one round after may increase.

The veneer thickness coefficient of variation decreases when the cutting path increases (Table 3 ). This is probably due to the constant over thickness induced by the presence of torn fibres at the surface of veneers, whatever peeling thickness. On the whole, according to the coefficient of variation value never exceeding $6 \%$, the peeling tests appear to have been correctly conducted.

Table 3. Thickness variations measured on green veneers

\begin{tabular}{|c|c|c|c|c|c|c|c|c|c|c|c|c|}
\hline Temperature & \multicolumn{9}{|c|}{$20^{\circ} \mathrm{C}$} & \multicolumn{7}{|c|}{$70^{\circ} \mathrm{C}$} \\
\hline Thickness (mm) & 1 & 3 & 5 & 1 & 3 & 5 & 1 & 3 & 5 & 1 & 3 & 5 \\
\hline Pressure bar & \multicolumn{3}{|c|}{ No PB } & \multicolumn{3}{|c|}{ PB } & \multicolumn{3}{c|}{ No PB } & \multicolumn{5}{c|}{ PB } \\
\hline Nber of measurements & 368 & 128 & 145 & 401 & 112 & 77 & 405 & 177 & 88 & 344 & 160 & 49 \\
\hline Mean thickness (mm) & 1.11 & 3.26 & 5.31 & 1.01 & 3.19 & 5.3 & 1.06 & 3.25 & 5.33 & 1.04 & 3.24 & 5.18 \\
\hline Coef. of variation (\%) & 5.65 & 4.05 & 3.17 & 5.46 & 3.39 & 2.44 & 3.96 & 3.41 & 2.32 & 1.38 & 3.15 & 3.39 \\
\hline
\end{tabular}

No lathe checks being detectible on $1 \mathrm{~mm}$ thick veneer, we have just reported the values for $3 \mathrm{~mm}$ and $5 \mathrm{~mm}$-thick veneers. The depth of the lathe checks are expressed as a percentage of veneer thickness.

The actions of the pressure bar and of temperature appear both to be efficient to decrease the depth of lathe checks but the pressure-bar effect seems predominant (Table 4). The results about lathe checks frequency (space between 2 checks) are atypical: usually thicker is the veneer, deeper and more spaced are lathe checks (Thibaut 1988). This last tendency is not clearly confirmed here: we have obviously to perform much more measurements to reinforce these tendencies. 
Table 4. Lathe checking measured on green veneers

\begin{tabular}{|c|c|c|c|c|c|c|c|c|c|c|c|c|}
\hline Temperature & \multicolumn{9}{|c|}{$20^{\circ} \mathrm{C}$} & \multicolumn{7}{c|}{$70^{\circ} \mathrm{C}$} \\
\hline Thickness (mm) & 1 & 3 & 5 & 1 & 3 & 5 & 1 & 3 & 5 & 1 & 3 & 5 \\
\hline Pressure bar & \multicolumn{3}{|c|}{ No PB } & \multicolumn{3}{c|}{ PB } & \multicolumn{3}{c|}{ No PB } & \multicolumn{3}{c|}{ PB } \\
\hline $\begin{array}{c}\text { Mean depth of checks / } \\
\text { veneer thickness (\%) }\end{array}$ & $\mathrm{a}_{-}$ & 57.3 & 56.9 & $\mathrm{a}_{-}$ & 39.9 & 52.4 & $\mathrm{a}_{-}$ & 43.5 & 58.4 & $\mathrm{a}_{-}$ & 39.6 & 38.6 \\
\hline $\begin{array}{c}\text { Mean space between } \\
\text { 2 checks (mm) }\end{array}$ & $\mathrm{a}_{-}$ & 4.2 & 5.1 & $\mathrm{a}_{-}$ & 6.9 & 5.5 & $\mathrm{a}_{-}$ & 6.1 & 5.1 & $\mathrm{a}_{-}$ & 13 & 5.3 \\
\hline
\end{tabular}

\section{LVL mechanical characteristics}

MOE obtained by the non destructive vibratory method show higher value than those obtained with the static 4-point bending method: the gap between the two sets of values is always around $2000 \mathrm{MPa}$. It is a quite standard difference between dynamic and static MOE. The two models Bernoulli (1748) and Timoshenko $(1921,1922)$ give very quite closed values and tendencies (Table 5).

Table 5. MOE of LVL measured non destructive vibratory method ( $\mathrm{E}=$ Edgewise $/ \mathrm{F}=$ Flatwise $/ \mu=$ mean value $/ \mathrm{CoV}=$ coefficient of variation)

\begin{tabular}{|c|c|c|c|c|c|c|c|c|c|c|c|c|c|c|}
\hline \multirow{2}{*}{\multicolumn{3}{|c|}{$\begin{array}{c}\text { Veneer thickness } \\
\text { Boiling temperature }\end{array}$}} & $1 \mathrm{~mm}$ & $3 \mathrm{~mm}$ & $5 \mathrm{~mm}$ & $1 \mathrm{~mm}$ & $3 \mathrm{~mm}$ & $5 \mathrm{~mm}$ & $1 \mathrm{~mm}$ & $3 \mathrm{~mm}$ & $5 \mathrm{~mm}$ & $1 \mathrm{~mm}$ & $3 \mathrm{~mm}$ & $5 \mathrm{~mm}$ \\
\hline & & & \multicolumn{6}{|c|}{$20^{\circ} \mathrm{C}$} & \multicolumn{6}{|c|}{$7^{\circ} \mathrm{C}$} \\
\hline \multicolumn{3}{|c|}{ Pressure bar (PB) } & \multicolumn{3}{|c|}{ Without BP } & \multicolumn{3}{|c|}{ With PB } & \multicolumn{3}{|c|}{ Without BP } & \multicolumn{3}{|c|}{ With PB } \\
\hline \multicolumn{3}{|c|}{ Number of tests } & 36 & 37 & 57 & 36 & 37 & 10 & 35 & 54 & 46 & 37 & 37 & 19 \\
\hline \multirow{10}{*}{$\begin{array}{c}\text { Ber- } \\
\text { nouilli }\end{array}$} & \multirow{5}{*}{$\mathrm{E}$} & $\mu(\mathrm{MPa})$ & 13942 & 12555 & 13308 & 13657 & 13180 & 13723 & 12831 & 13172 & 13424 & 14300 & 11732 & 13741 \\
\hline & & $\mathrm{CoV}(\%)$ & 5.0 & 6.9 & 5.1 & 5.2 & 4.2 & 5.1 & 6.8 & 4.4 & 4.0 & 2.5 & 11.4 & 5.5 \\
\hline & & \multirow{3}{*}{$\mu(\mathrm{MPa})$} & \multicolumn{3}{|c|}{13268} & \multicolumn{3}{|c|}{13520} & \multicolumn{3}{|c|}{13142} & \multicolumn{3}{|c|}{13258} \\
\hline & & & \multicolumn{6}{|c|}{13394} & \multicolumn{6}{|c|}{13200} \\
\hline & & & \multicolumn{12}{|c|}{13297} \\
\hline & \multirow{5}{*}{$\mathrm{F}$} & $\mu(\mathrm{MPa})$ & 14594 & 12544 & 12931 & 13578 & 13208 & 12576 & 13075 & 13419 & 13589 & 14663 & 11781 & 13002 \\
\hline & & CoV (\%) & 5.4 & 8.3 & 7.1 & 5.9 & 4.8 & 9.1 & 7.2 & 5.3 & 5.4 & 2.0 & 11.4 & 7.1 \\
\hline & & \multirow{3}{*}{$\mu(\mathrm{MPa})$} & \multicolumn{3}{|c|}{13356} & \multicolumn{3}{|c|}{13121} & \multicolumn{3}{|c|}{13361} & \multicolumn{3}{|c|}{13149} \\
\hline & & & \multicolumn{6}{|c|}{13239} & \multicolumn{6}{|c|}{13255} \\
\hline & & & \multicolumn{12}{|c|}{13247} \\
\hline \multirow{10}{*}{$\begin{array}{l}\text { Timo- } \\
\text { shenko }\end{array}$} & & $\mu(\mathrm{MPa})$ & 14482 & 13073 & 13982 & 14022 & 13678 & 14439 & 13209 & 13420 & 13971 & 14869 & 12212 & 14246 \\
\hline & & $\operatorname{CoV}(\%)$ & 5.2 & 6.7 & 5.7 & 5.0 & 4.4 & 4.9 & 7.0 & 4.2 & 4.1 & 2.5 & 11.4 & 5.3 \\
\hline & E & & & 13845 & & & 14046 & & & 13534 & & & 13776 & \\
\hline & & $\mu(\mathrm{MPa})$ & & & 139 & 46 & & & & & & 55 & & \\
\hline & & & & & & & & & & & & & & \\
\hline & & $\mu(\mathrm{MPa})$ & 15126 & 13032 & 13397 & 13938 & 13646 & 13096 & 13423 & 13596 & 14068 & 15224 & 12221 & 13455 \\
\hline & & $\mathrm{CoV}(\%)$ & 5.6 & 7.7 & 7.3 & 5.8 & 5.0 & 9.3 & 7.0 & 5.0 & 5.6 & 2.0 & 11.5 & 7.2 \\
\hline & $\mathrm{F}$ & & & 13852 & & & 13560 & & & 13696 & & & 13633 & \\
\hline & & $\mu(\mathrm{MPa})$ & & & 13 & 06 & & & & & & & & \\
\hline & & & & & & & & & & & & & & \\
\hline Boa & $\mathrm{d} d$ & ensity & 0.91 & 0.77 & 0.72 & 0.88 & 0.77 & 0.68 & 0.84 & 0.72 & 0.73 & 0.85 & 0.76 & 0.71 \\
\hline
\end{tabular}

The ANOVA (Table 6) shows (i) very strong interactions effects between veneer thickness, temperature and the presence of pressure bar (Figure 8) (ii) a very important veneer thickness effect, a temperature effect (with Timoshenko $(1921,1922)$ model, the most completed model) and an orientation effect but no pressure bar effect. Almost $50 \%$ of the variability could be explained by these 4 factors. 
Table 6. ANOVA for the MOE measured with the Bing method (4 independent variables: wood temperature, veneer thickness, pressure bar action, stress direction / 2 dependant variables: Bernouilli MOE (B), Timoshenko MOE (T)

\begin{tabular}{|l|c|c|c|c|c|c|c|}
\cline { 2 - 8 } \multicolumn{1}{c|}{} & \multirow{2}{*}{ df } & \multicolumn{3}{c|}{ F } & \multicolumn{2}{c|}{ p } & \multicolumn{2}{c|}{$\mathbf{r}^{2}$} \\
\cline { 2 - 8 } \multicolumn{1}{c|}{} & & $\mathbf{B}$ & $\mathbf{T}$ & $\mathbf{B}$ & $\mathbf{T}$ & $\mathbf{B}$ & $\mathbf{T}$ \\
\hline (1) Thickness & $\mathbf{2}$ & $\mathbf{1 5 4 . 6}$ & $\mathbf{1 5 5 . 8}$ & $\mathbf{0 . 0 0 0}$ & $\mathbf{0 . 0 0 0}$ & $\mathbf{1 8 . 9}$ & $\mathbf{1 9 . 0}$ \\
\hline$(2)$ Temperature & 1 & $\mathbf{1 . 4}$ & $\mathbf{7 . 3}$ & $\mathbf{0 . 2 4 4}$ & $\mathbf{0 . 0 0 7}$ & 0.1 & 0.4 \\
\hline$(3)$ Pressure bar & 1 & $\mathbf{0 . 9}$ & $\mathbf{0}$ & $\mathbf{0 . 3 4 2}$ & $\mathbf{0 . 9 0 9}$ & 0.1 & 0.0 \\
\hline$(4)$ Orientation (fatwise/edgewise) & 1 & $\mathbf{1 . 1}$ & $\mathbf{4 . 8}$ & $\mathbf{0 . 3 0 1}$ & $\mathbf{0 . 0 3 0}$ & 0.1 & 0.3 \\
\hline$(1) *(2)$ & 2 & $\mathbf{2 0 . 3}$ & $\mathbf{1 9}$ & $\mathbf{0 . 0 0 0}$ & $\mathbf{0 . 0 0 0}$ & 2.5 & 2.3 \\
\hline$(1) *(3)$ & 2 & $\mathbf{2 6 . 5}$ & $\mathbf{2 0 . 4}$ & $\mathbf{0 . 0 0 0}$ & $\mathbf{0 . 0 0 0}$ & 3.2 & 2.5 \\
\hline$(2) *(3)$ & 1 & 0 & $\mathbf{4 . 5}$ & 0.835 & $\mathbf{0 . 0 3 5}$ & 0.0 & 0.3 \\
\hline$(1) *(4)$ & 2 & $\mathbf{2 2 . 3}$ & $\mathbf{2 6 . 5}$ & $\mathbf{0 . 0 0 0}$ & $\mathbf{0 . 0 0 0}$ & 2.7 & 3.2 \\
\hline$(2) *(4)$ & 1 & 4.2 & $\mathbf{5 . 3}$ & 0.042 & $\mathbf{0 . 0 2 2}$ & 0.3 & 0.3 \\
\hline$(3) *(4)$ & 1 & 16.3 & $\mathbf{1 4 . 8}$ & 0.000 & $\mathbf{0 . 0 0 0}$ & 1.0 & 0.9 \\
\hline$(\mathbf{1}) *(\mathbf{2}) *(3)$ & $\mathbf{2}$ & $\mathbf{1 5 2 . 7}$ & $\mathbf{1 4 7 . 5}$ & $\mathbf{0 . 0 0 0}$ & $\mathbf{0 . 0 0 0}$ & $\mathbf{1 8 . 6}$ & $\mathbf{1 8 . 0}$ \\
\hline$(1) *(2) *(4)$ & 2 & 2.2 & $\mathbf{3 . 4}$ & 0.116 & $\mathbf{0 . 0 3 3}$ & 0.3 & 0.4 \\
\hline$(1) *(3) *(4)$ & 2 & 7.2 & $\mathbf{6 . 5}$ & 0.001 & $\mathbf{0 . 0 0 2}$ & 0.9 & 0.8 \\
\hline$(2) *(3) *(4)$ & 1 & 1 & 1.3 & 0.321 & 0.260 & 0.1 & 0.1 \\
\hline$(1) *(2) *(3) *(4)$ & 2 & $\mathbf{2 . 4}$ & $\mathbf{2}$ & $\mathbf{0 . 0 9 4}$ & $\mathbf{0 . 1 3 0}$ & 0.3 & 0.3 \\
\hline
\end{tabular}

Indeed MOE (Timoshenko 1953) is always decreasing between 1 and $3 \mathrm{~mm}$, except on LVL with veneers peeled at $70^{\circ} \mathrm{C}$ without any pressure bar (Figure 8c). But after, MOE increases between 3 and 5 $\mathrm{mm}$ in near all cases. We can also observe that MOE obtained flatwise and edgewise are always closed except for LVL with thick veneers $(5 \mathrm{~mm})$ where MOE obtained flatwise show lower values.

There is obviously a strong veneer thickness effect but the evolution of MOE with this parameter is not monotone and it appears that, according to MOE values measured by a vibratory method, LVL with thick veneers appears to be stiffer than those with conventional veneers $3 \mathrm{~mm}$ thick, but it could be due to an experimental bias. This point will be discussed farther.

The 4-point bending tests show a very strong thickness effect, a temperature effect but not any pressure bar effect both for static MOE and MOR ( Timoshenko and Goodier 1961 ) (Table 7). MOE and MOR evolution are parallel. These evolutions are always monotone and decreasing for LVL with veneers peeled at room temperature (Figures $8 \mathrm{a}$ and $8 \mathrm{~b}$ ) but we can notice a higher point for LVL with $3 \mathrm{~mm}$ thick veneers peeled at $70^{\circ} \mathrm{C}$ without pressure bar (figure 8c) and a lower point for the same thickness when peeling at the same temperature but with a pressure bar acting (Figure 8d). These last results are unexpected as we know that the greater dispersion of defects in LVL, then the better mechanical properties, is obtained when multiplying the number of layers. That is another reason to explain that LVL composed of thin veneers usually show the best mechanical properties. But these surprising results can be partly explained considering two experimental biases occurring during boards manufacturing:

after a careful examination of the samples, it appears that some low mechanical values were obtained on boards including residual knots into the veneers while these defects were supposed to have been completely removed before gluing. It is particularly true for the combinations $1 \mathrm{~mm}$ thick $/ 70^{\circ} \mathrm{C}$ / no pressure bar and $3 \mathrm{~mm} / 70^{\circ} \mathrm{C} /$ pressure bar. 
- $\quad$ the gluing time being directly proportional to the number of glue lines, thinner the veneers are and higher was the "open time" and the number of possible defective glue joints. Furthermore, the room temperature was not constant $\left(18^{\circ} \mathrm{C}+/-3^{\circ} \mathrm{C}\right)$ all along the period of gluing.

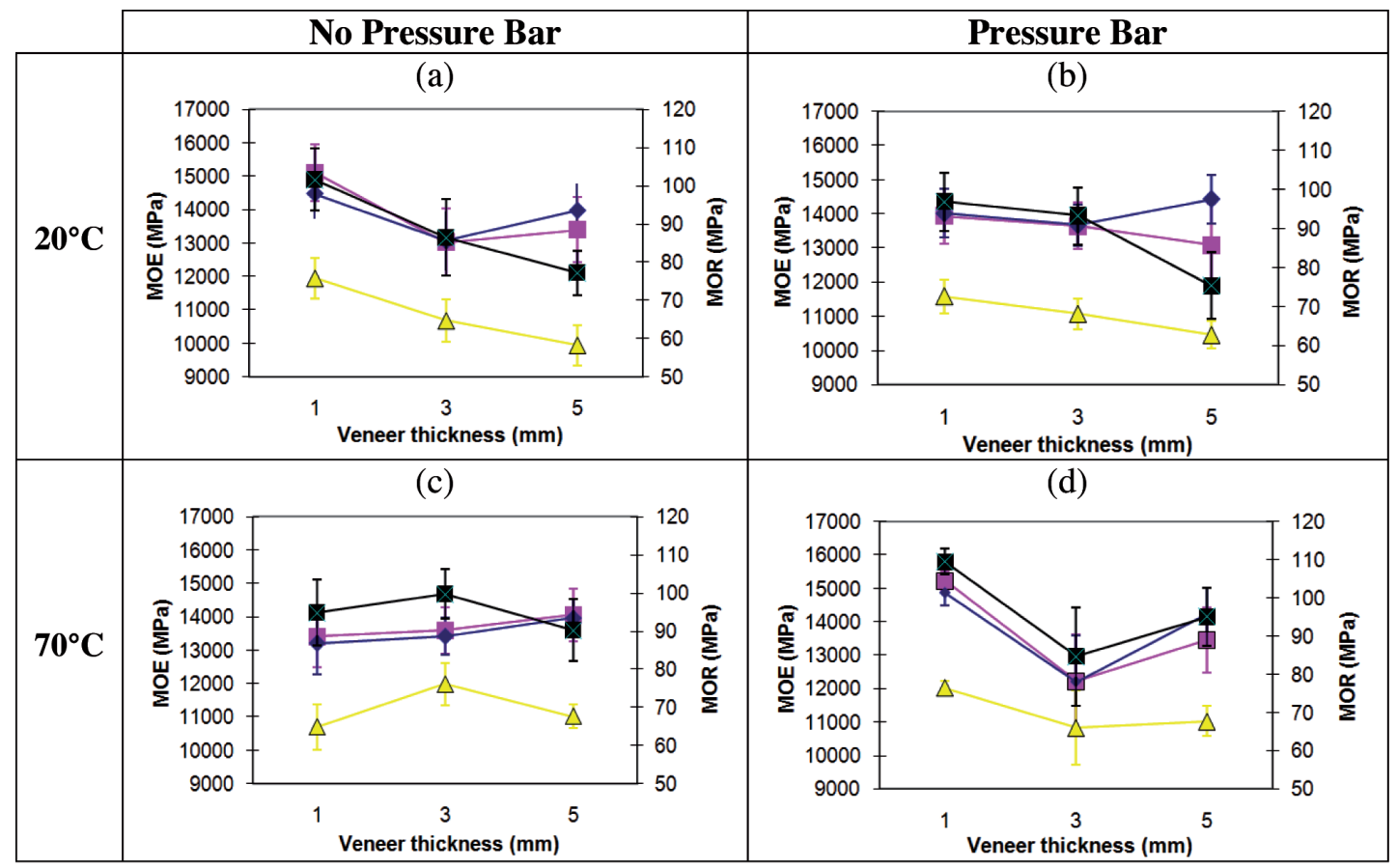

Figure 8. Evolutions of LVL mechanical properties with veneer thickness, boiling temperature and pressure bar action (For the BING test, only Timoshenko MOE values are displayed - For static test, MOE is obtained edgewise)

Table 7. ANOVA for the mechanical properties measured with the 4-point bending test (3 independent variables: wood temperature, veneer thickness, pressure bar action / 2 dependant variables: static MOE, static MOR (edgewise))

\begin{tabular}{|l|c|r|r|c|c|}
\cline { 2 - 6 } \multicolumn{1}{c|}{} & \multirow{2}{c|}{ df } & \multicolumn{2}{c|}{ F } & \multicolumn{2}{c|}{ p } \\
\cline { 3 - 6 } \multicolumn{1}{c|}{} & MOE & MOR & MOE & MOR \\
\hline (1) Thickness & $\mathbf{2}$ & $\mathbf{4 5 . 6}$ & $\mathbf{7 5 . 6}$ & $\mathbf{0 . 0 0 0}$ & $\mathbf{0 . 0 0 0}$ \\
\hline (2) Temperature & 1 & $\mathbf{1 4 . 2}$ & $\mathbf{3 7 . 2}$ & $\mathbf{0 . 0 0 0}$ & $\mathbf{0 . 0 0 0}$ \\
\hline (3) Presence of pressure bar & 1 & 1.0 & 0.7 & 0.315 & 0.413 \\
\hline $\mathbf{( 1 )} *(\mathbf{2})$ & 2 & $\mathbf{2 0 . 4}$ & $\mathbf{1 5 . 0}$ & $\mathbf{0 . 0 0 0}$ & $\mathbf{0 . 0 0 0}$ \\
\hline $\mathbf{( 1 )} *(\mathbf{3})$ & 2 & $\mathbf{1 1 . 0}$ & $\mathbf{5 . 7}$ & $\mathbf{0 . 0 0 0}$ & $\mathbf{0 . 0 0 4}$ \\
\hline$(2) *(3)$ & 1 & 0.1 & 1.0 & 0.707 & 0.323 \\
\hline $\mathbf{( 1 )} *(\mathbf{2}) *(3)$ & 2 & $\mathbf{3 7 . 6}$ & $\mathbf{3 1 . 5}$ & $\mathbf{0 . 0 0 0}$ & $\mathbf{0 . 0 0 0}$ \\
\hline
\end{tabular}


The static MOE evolution is not always in good concordance with those of dynamic MOE, especially for LVL with the thicker veneers. It comes out that thicker the veneers are and weaker are the correlation between the non destructive and the destructive measurements (Table 8). This is probably linked to the lathe checking increase with veneer thickness (Table 4) which induce more heterogeneity into the boards and so more scattered mechanical results when using vibratory methods (Figure 8 for thickness $5 \mathrm{~mm})$.

Table 8. Correlation coefficients between MOE obtained by BING method and MOE \& MOR obtained by the 4-point bending method

\begin{tabular}{|l|c|c|c|c|c|c|c|c|}
\cline { 2 - 9 } \multicolumn{1}{c|}{} & \multicolumn{2}{c|}{ All thicknesses } & \multicolumn{2}{c|}{$1 \mathrm{~mm}$} & \multicolumn{2}{c|}{$3 \mathrm{~mm}$} & \multicolumn{2}{c|}{$5 \mathrm{~mm}$} \\
\cline { 2 - 9 } \multicolumn{1}{c|}{} & $\begin{array}{c}\text { MOE } \\
\text { 4-point }\end{array}$ & $\begin{array}{l}\text { MOR } \\
\text { 4-point }\end{array}$ & $\begin{array}{c}\text { MOE } \\
\text { 4-point }\end{array}$ & $\begin{array}{l}\text { MOR } \\
\text { 4-point }\end{array}$ & $\begin{array}{c}\text { MOE } \\
\text { 4-point }\end{array}$ & $\begin{array}{l}\text { MOR } \\
\text { 4-point }\end{array}$ & $\begin{array}{c}\text { MOE } \\
\text { 4-point }\end{array}$ & $\begin{array}{l}\text { MOR } \\
\text { 4-point }\end{array}$ \\
\hline $\begin{array}{l}\text { MOE BING edgewise } \\
\text { (Timoshenko) }\end{array}$ & $\mathbf{0 . 5 9}$ & $\mathbf{0 . 5 1}$ & 0.89 & 0.76 & 0.75 & 0.75 & 0.44 & 0.47 \\
\hline $\begin{array}{l}\text { MOE BING flatwise } \\
\text { (Timoshenko) }\end{array}$ & $\mathbf{0 . 7 1}$ & $\mathbf{0 . 6 9}$ & 0.96 & 0.83 & 0.79 & 0.79 & 0.49 & 0.35 \\
\hline
\end{tabular}

Nevertheless, it appears again, even considering MOR, that LVL with $5 \mathrm{~mm}$ thick veneers obtained after boiling and with a pressure bar can be stronger than conventional LVL.

Concerning the 5-point bending tests, all the ruptures occur by bending in the $1 \mathrm{~mm}-\mathrm{LVL}$ and by shearing for near all the $5 \mathrm{~mm}$-LVL. The intermediate LVL ( $3 \mathrm{~mm}$ thick veneers) is also intermediate for the mode of rupture: $42 \%$ of the test pieces break by bending, and $58 \%$ by shearing (Table 9 ), the proportion of rupture in bending mode increasing with the veneer quality. It appears also that LVL presents higher shear strength when loaded flatwise (glue bonds stressed) than edgewise: lathe checking seems to just lightly affects LVL glue bonds strength but much more wood layers (veneers) strength. Accordingly, if using squared LVL, it could be better to position the beam in order to load it flatwise, especially for LVL with $5 \mathrm{~mm}$ thick veneer.

Table 9. Five-point bending test: shear failure occurrence and values

\begin{tabular}{|c|c|c|c|c|c|c|c|c|c|c|c|c|}
\hline Temperature & \multicolumn{9}{|c|}{$20^{\circ} \mathrm{C}$} & \multicolumn{5}{c|}{$70^{\circ} \mathrm{C}$} \\
\hline Thickness (mm) & 1 & 3 & 5 & 1 & 3 & 5 & 1 & 3 & 5 & 1 & 3 & 5 \\
\hline Pressure bar & \multicolumn{3}{|c|}{ No PB } & \multicolumn{3}{c|}{ PB } & \multicolumn{3}{c|}{ No PB } & \multicolumn{3}{c|}{ PB } \\
\hline
\end{tabular}

Flatwise

\begin{tabular}{|l|c|c|c|c|c|c|c|c|c|c|c|c|}
\hline Nber of measurements & 8 & 9 & 14 & 9 & 9 & 10 & 9 & 13 & 10 & 9 & 9 & 5 \\
\hline \% of shear failure & $\mathbf{0}$ & $\mathbf{3 3}$ & $\mathbf{8 6}$ & $\mathbf{0}$ & $\mathbf{8 9}$ & $\mathbf{1 0 0}$ & $\mathbf{0}$ & $\mathbf{6 2}$ & $\mathbf{1 0 0}$ & $\mathbf{0}$ & $\mathbf{2 2}$ & $\mathbf{4 0}$ \\
\hline Shear strength (MPa) & $*$ & $\mathbf{9 9}$ & $\mathbf{8 7}$ & $*$ & $\mathbf{1 1 6}$ & $\mathbf{9 8}$ & $*$ & $\mathbf{1 1 7}$ & $\mathbf{1 0 6}$ & $*$ & $\mathbf{1 1 8}$ & $\mathbf{1 0 9}$ \\
\hline Coef of variation $(\%)$ & $*$ & 7 & 8 & $*$ & 3 & 11 & $*$ & 7 & 5 & $*$ & 4 & 0 \\
\hline
\end{tabular}

Edgewise

\begin{tabular}{|l|c|c|c|c|c|c|c|c|c|c|c|c|}
\hline Nber of measurements & 10 & 10 & 14 & 9 & 10 & 10 & 9 & 14 & 12 & 10 & 10 & 5 \\
\hline \% of shear failure & $\mathbf{0}$ & $\mathbf{9 0}$ & $\mathbf{1 0 0}$ & $\mathbf{0}$ & $\mathbf{1 0 0}$ & $\mathbf{1 0 0}$ & $\mathbf{0}$ & $\mathbf{6 4}$ & $\mathbf{1 0 0}$ & $\mathbf{0}$ & $\mathbf{0}$ & $\mathbf{1 0 0}$ \\
\hline Shear strength (MPa) & $*$ & $\mathbf{8 5}$ & $\mathbf{5 9}$ & $*$ & $\mathbf{9 3}$ & $\mathbf{5 6}$ & $*$ & $\mathbf{1 0 1}$ & $\mathbf{7 5}$ & $*$ & $*$ & $\mathbf{8 5}$ \\
\hline Coef of variation $(\%)$ & $*$ & 5 & 10 & $*$ & 7 & 9 & $*$ & 8 & 13 & $*$ & $*$ & 8 \\
\hline
\end{tabular}


Correlation between veneer quality parameters and LVL mechanical properties

For each of the 24 LVL boards, we have computed the mean value of

- veneer quality criteria (roughness, thickness variation, lathe checks frequency and amplitude);

- the mechanical characteristics obtained on from each board (MOEs, MOR, percentage of shearing rupture obtained in 5-point bending test).

We have then computed the correlation coefficients $r$ between the two sets of data (Table 10) in order to grade the veneer quality factors for their influence on LVL mechanical properties. Despite of having used perfectible methods for veneer quality assessments, we can observe some interesting tendencies:

- $\quad$ veneer quality can’t help to predict MOEs obtained when loading flatwise;

- roughness value is here the more related to LVL mechanical properties, especially loaded edgewise. This criterion is better correlated with static mechanical properties than lathe checking parameters are;

- $\quad$ veneer thickness variation - quite low here - does not significantly affect LVL mechanical properties;

- the two criteria "checks deepness" and "difference of roughness between the loose and the tight side" describing lathe checking give very closed results and are significantly correlated to static mechanical values (deeper the lathe checks are and lower are the mechanical values).

- Theses results have to be confirmed using a more adapted veneer metrology and using more "homogeneous" boards for a given veneer quality criterion, in order to organize in a hierarchy the different criteria of veneer quality and then to act on the peeling parameters and settings with full knowledge of the facts.

Table 10. Correlation coefficients $r$ between veneer qualities and LVL mechanical properties ( $\mathrm{T}=$ Timoshenko model, $\mathrm{B}=$ Bernouilli model, $5 \mathrm{P}=5$-point bending test $)$

\begin{tabular}{|c|c|c|c|c|c|c|c|c|}
\hline & \multicolumn{3}{|c|}{ Flatwise } & \multicolumn{5}{|c|}{ Edgewise } \\
\hline & $\begin{array}{c}\text { MOE } \\
\text { BING } \\
(\mathrm{T})\end{array}$ & $\begin{array}{c}\text { MOE } \\
\text { BING } \\
\text { (B) }\end{array}$ & \multirow{2}{*}{$\begin{array}{c}5 \mathrm{P} \% \\
\text { shearing } \\
\text { failure }\end{array}$} & $\begin{array}{c}\text { MOE } \\
\text { BING } \\
\text { (T) }\end{array}$ & $\begin{array}{c}\text { MOE } \\
\text { BING } \\
\text { (B) }\end{array}$ & $\begin{array}{l}\text { MOE } \\
\text { 4-point }\end{array}$ & $\begin{array}{l}\text { MOR } \\
\text { 4-point }\end{array}$ & \multirow{2}{*}{$\begin{array}{c}5 \mathrm{P} \% \\
\text { shearing } \\
\text { failure }\end{array}$} \\
\hline & \multicolumn{2}{|c|}{$(\mathrm{MPa})$} & & \multicolumn{4}{|c|}{$(\mathrm{MPa})$} & \\
\hline $\begin{array}{l}\text { (1) Loose-side roughness } \\
\text { (mm of water) }\end{array}$ & 0.31 & 0.36 & -0.75 & 0.52 & 0.52 & 0.50 & 0.69 & -0.75 \\
\hline $\begin{array}{l}\text { (2) Tight-side roughness } \\
\text { (mm of water) }\end{array}$ & 0.28 & 0.36 & -0.79 & 0.56 & 0.57 & 0.62 & 0.78 & -0.76 \\
\hline$(2)-(1)$ & 0.01 & 0.11 & -0.31 & 0.26 & 0.31 & 0.50 & 0.43 & -0.25 \\
\hline Checks deepness (\%) & 0.34 & 0.24 & 0.39 & 0.21 & 0.13 & -0.49 & -0.47 & 0.49 \\
\hline $\begin{array}{l}\text { Distance between } \\
2 \text { checks }(\mathrm{mm})\end{array}$ & -0.59 & -0.54 & -0.39 & -0.40 & -0.34 & 0.28 & 0.17 & -0.79 \\
\hline $\begin{array}{l}\text { Thickness Coefficient of } \\
\text { Variation }(\%)\end{array}$ & -0.26 & -0.20 & -0.50 & -0.01 & 0.01 & 0.06 & 0.06 & -0.39 \\
\hline
\end{tabular}


Table 11. Glue consumption to manufacture each LVL board

\begin{tabular}{|c|c|c|c|c|c|c|c|c|c|c|c|c|}
\hline Bolt number & 14 & 4 & 15 & 13 & 4 & 14 & 19 & 17 & 3 & 18 & 16 & 11 \\
\hline Veneer thickness [mm] & 1 & 3 & 5 & 1 & 3 & 5 & 1 & 3 & 5 & 1 & 3 & 5 \\
\hline Number of glue lines & 19 & 6 & 3 & 19 & 6 & 3 & 19 & 6 & 3 & 19 & 6 & 3 \\
\hline Boiling temperature & \multicolumn{6}{|c|}{$20^{\circ} \mathrm{C}$} & \multicolumn{6}{|c|}{$70^{\circ} \mathrm{C}$} \\
\hline Pressure bar (PB) & \multicolumn{3}{|c|}{ Without BP } & \multicolumn{3}{|c|}{ With PB } & \multicolumn{3}{|c|}{ Without BP } & \multicolumn{3}{|c|}{ With PB } \\
\hline Mean glue spread $\left(\mathrm{g} / \mathrm{m}^{2}\right)$ & 276 & 303 & 392 & 269 & 292 & 407 & 287 & 308 & 390 & 290 & 326 & 419 \\
\hline Glue / wood ratio (\%) & 29 & 12 & 9 & 34 & 11 & 8 & 29 & 12 & 9 & 32 & 13 & 6 \\
\hline
\end{tabular}

\section{CONCLUSIONS}

We have presented here the results of preliminary tests showing that the weakening of LVL mechanical characteristics with the increase of veneer thickness in the range 1 to $5 \mathrm{~mm}$ appears limited. This observation makes us optimistic to consider manufacturing LVL with both low glue rates and good mechanical properties. But, as can be seen in table 11, the increase of veneer thickness induces an increase of glue spread because of the degradation of veneer surface topography. Even if the over-consumption is quite limited, we should notice that dividing the number of glue lines by a given factor does not induce to divide glue consumption exactly by the same factor but by a lower one.

The non destructive prediction of MOE by vibration seems not so good on LVL composed of thick veneers, especially in the case of edgewise loading, probably because of the presence of important lathe checks.

In some configuration, and especially when using thick veneers, it could be benefit to load LVL flatwise rather than edgewise.

Concerning the 5-point bending test, this work raises the issue of the domain of validity of such a method to estimate the shear strength of LVL. Some other tests should absolutely to be done in order to correlate the results obtained here to others made on the same sampling but using more conventional shearing tests.

In order to correctly classify veneer properties influencing LVL mechanical behavior, these exploratory experiments have taught us that for the next step we should

- $\quad$ carefully select the veneers for a given criteria to make homogeneous boards for this criteria instead of making boards exclusively composed with veneer obtained with the same peeling settings. This approach would also permit link microstructure observations made on veneers or LVL to mechanical behaviors;

- $\quad$ improve the boards manufacturing conditions particularly when gluing;

- $\quad$ improve veneer quality metrology.

To go ahead to enhance the environmental and mechanical properties of LVL, we should also

- conduct numerical model of LVL mechanical behavior coupled to experiments, introducing different rate of lathe check,

- $\quad$ test higher veneer thicknesses (7 to $10 \mathrm{~mm}$ ), different size and distribution of wood defects and different load directions and repeat the research on softwood species. 


\section{REFERENCES}

ASTM D2718. 2006. Standard Test Methods for Structural Panels in Planar Shear (Rolling Shear), $6 \mathrm{p}$.

BING. 2007. www.xylo-metry.org/en/bing.html. (Online Diciembre 2010)

Bernoulli, D. 1748. Réflexion et Eclaircissement sur les Nouvelles Vibrations des Cordes Exposées dans les Mémoires de l'Académie. Royal Academy of Berlin p.1750

Ebihara, T. 1982. The performance of composite beams with laminated-veneer lumber. Mokuzai Gakkaishi 28 (8): 216-224

Echols, R.M.; Currier, R.A. 1973. Comparative properties of Douglas-Fir made from ParallelLaminated Veneers vs Solid Wood. Forest Products Journal 23 (2): 45-47

Hoover, W.L.; Ringe J.M.; Eckelman, C.A.; Youngquist, J.A. 1987. Material design factors for hardwood laminated-veneer-lumber. Forest Products Journal 37(9): 15-23

Kilic, Y.; Colak, N.; Baysal, E.; Burdurlu, E. 2006. An investigation of some physical and mechanical properties of laminated veneer lumber manufactured from black alder (Alnus glutinosa) glued with polyvinyl acetate and polyurethane adhesives. Forest Products Journal 56(9): 56-59

Kunesh, R.H. 1978. Micro-Lam: structural Laminated Veneer Lumber. Forest Products Journal 28 (7): 41-44

Lei, Y. K.; Wilson, J.B. 1979. Fracture toughness of parallel-laminated veneer. Forest Products Journal 29 (8): 28-31

Moody R.C. 1972. Tensile strength of lumber laminated from $1 / 8$-inch-thick veneers. Research paper FPL n $181,28 \mathrm{p}$.

Moriizumi, S.; Maeda, N.; Sanada, Y.; Ogura, T. 1984. The strength properties of Japanese larch LVL (I). The wood quality of small Japanese larch logs and the bending strength of clear LVL Journal of the Hokkaido. Forest Products Research Institute 1984 n $^{\circ} 384,1-7$

NF B51-008. 1987. Wood. Static bending. Determination of ultimate strength in static bending using small clear specimens", November 1987, 8 p.

NF B51-016. 1987. Wood. Static bending. Determination of modulus of elasticity in static bending using small clear specimens, December 1987, 8 p.

Pałubicki, B.; Marchal, R.; Butaud, J.C.; Denaud, L. E.; Bléron L.; Collet, R.; Kowaluk, G. 2009. A Method of Lathe Checks Measurement; SMOF device and its software. In press, Wood Science and Technology.

Schaffer, E.L.; Jokerst, R.W.; Moody, R.C.; Peters, C.C.; Tschernitz, J.L.; Zahnj, J. 1972. Feasibility of producing a high-yield laminated structural product: general summary. Reseach paper FPL $n^{\circ} 175,18 \mathrm{p}$. 
Thibaut, B. 1988. Le processus de coupe du bois par déroulage. PhD Thesis, University of Montpellier, $386 \mathrm{p}$.

Timoshenko, S. 1921. On the Correction for Shear of the Differential Equation for Transverse Vibrations of Prismatic Bars. Philosophical Magazine of Science. XLI-Sixth Series: 744-746

Timoshenko, S. 1922. On the Transverse Vibrations of Bars of Uniform Cross-Section. Philosophical Magazine of Science. XLIII-Sixth Series: 125-131

Timoshenko, S. 1953. Résistance des matériaux, partie I, Théorie Elémentaire et Problèmes. Libraire Polytechnique Béranger(Ed).Paris. pp.284-288

Timoshenko, S. ; Goodier, J.N. 1961. Théorie de l'élasticité. Libraire Polytechnique Béranger(Ed). Paris. pp.279-284, 341-368

Watanuki, Y.; Taguri, T.; Nakamura, K. 1983. Utilization of hardwood laminated-veneer lumber as furniture-frame stock. Journal of the Japan Wood Research Society 29(5): 375-381

Youngquist, J.A.; Bryant, B.S. 1979. Production and marketing feasibility of parallel-laminated veneer products. Forest Products Journal 29 (8):45-48

Youngquist, J.A.; Laufenberg, T.L.; Bryant, B.S. 1984. End jointing of laminated veneer lumber for structural use. Forest Products Journal 34(11-12): 25-32

Zahn, J.J. 1972. Feasibility of producing a high-yield laminated structural product : General Summary. Research paper FPL n ${ }^{\circ} 175,18$. 
